\title{
Reinvente a madeira
}

Miriam Mirna Korolkovas

MMK, mmkorolkovas@gmail.com

São Paulo, Brasil

Peltogyne spp., Aspidosperma polyneuron e Ceiba speciosa, entre outras.

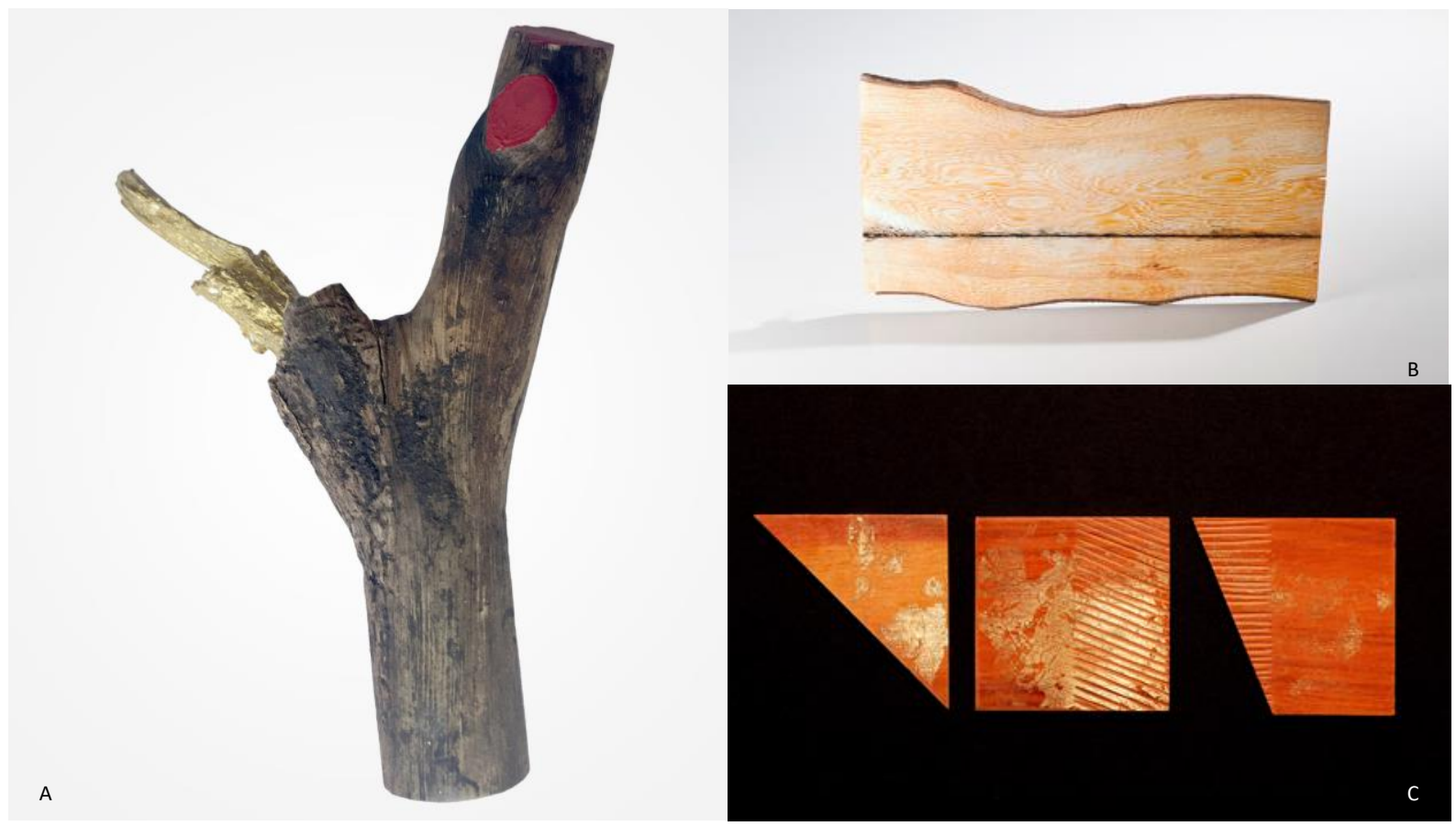

Figura A: Broche de fragmento de galho de árvore com bronze esculpido e inserido nele - a tinta vermelha no corte significa o sangue derramado - parte da série denominada "Apocalipse 11:18”; Figura B: Broche de madeira com grafite; Figura C: Tríptico: broches em peroba rosa, a partir de piso taco encontrado em caçamba - superfície tratada com goiva e folhas de ouro mil, fazendo referência à extração de látex dos seringais do Acre.

RESUMO: O relato apresenta o trabalho desenvolvido pela autora a partir da madeira recuperada no âmbito das artes plásticas, com ênfase no setor de ornamentação corporal. A abordagem contempla quatro aspectos das atividades da autora. No primeiro, "coleta", apresenta-se as formas e locais de obtenção, o tipo de material coletado abrangendo seções de tronco, raízes, galhos e folhas - e o estado em que se encontram. O segundo, "protesto", trata do ativismo realizado pela autora junto às árvores urbanas que são objeto de podas inadequadas, incluindo o uso de tinta vermelha, laços de tule branco e até faixas pretas com inscrições como "luto". O terceiro aborda um trabalho voluntário desenvolvido na Floresta Nacional de Caxiuanã, no Pará, abrangendo a realização de oficinas de produção de adornos para jovens moradores de comunidades locais. Por fim são mostrados alguns exemplos do vasto e diversificado trabalho da autora nos setores mencionados.

Palavras-chave: artes plásticas, ativismo, madeira urbana, ornamentação corporal.
ABSTRACT: The report presents the author's work developed with reclaimed wood within the framework of plastic arts, mainly in the field of body ornamentation. The approach encompasses four aspects of her activities. In the first one, "collection", ways, places of collection and types of gathered material are shown - including trunk sections, roots, branches, and leaves - as well as their physical conditions. The second one, "protest", reveals the author's activism related to the urban trees victimized by inadequate pruning, including painting injured parts of the trees with red ink, bonding them with white tulle ribbons and even fixing black plastic banners near them, with protest words such as "grief". The third one tells about a volunteer work realized in the Caxiuanã National Forest, at Para State, comprising workshops for body adornments creation, with local communities' young inhabitants. Finally, some samples of the vast and diverse author's work on the mentioned sectors are shown.

Keywords: plastic arts, activism, urban wood, body ornamentation. 